Preface

\title{
Science based management of coastal waters
}

\author{
Éric J.M. Delhez*, Alexander Barth \\ MARE-InterfacultaryCenter for Marine Research, University of Liège
}

The 41st International Liege Colloquium on Ocean Dynamics provided a forum to present and discuss scientific advances in the field of Integrated Coastal Zone Management, to compare the modelling and experimental approaches set up in various case studies and to identify the need for future developments. The diversity of the topics addressed during the colloquium, which is reflected in the papers published in this special issue, demonstrates the variety of the related scientific issues.

Coastal zones have a very high strategic importance. They accommodate indeed more than $60 \%$ of the world's population, provide major sources of food and raw materials, form a vital link for transport and trade, support intense economic activity, offer recreational opportunities and support countless unique ecosystems. Most coastal zones suffer however from frequent conflicts between these uses. Many contaminants (metals, xenobiotics, nutrients...) are brought to the river surface waters and ground waters. A significant but largely unknown part of the contaminants finally reaches the estuaries and affects the coastal waters, often beyond the limits of territorial waters. The whole aquatic continuum, stretching well over the political and administrative units, must therefore be considered when assessing the impact of pollution problems and the efficiency of mitigation plans.

The complex hydrodynamics of coastal regions and, in particular, the influence of mesoscale features on the offshore transport and mixing require specific observation and modelling systems (Hu et al., 2011-this issue; Casella et al., 2011-this issue; Pairaud et al., 2011this issue; Hoitink et al., 2011-this issue), including data assimilation (Grayek et al., 2011-this issue), that combine into operational systems (Grifoll et al., 2011-this issue).

The coastal erosion/siltation patterns in coastal waters are influenced by both local small scale and large scale processes (Soomere et al., 2011-this issue; Iosjpe, 2011-this issue) whose complex non-linear interactions must be carefully taken into account (Ribas et al., 2011-this issue; van den Berg et al., 2011-this issue) to describe and predict the long term morphological changes.

While major changes of aquatic ecosystems are clearly related to human activity (growing population, urbanisation, industrial activity, intensive farming), the direct link between the pressures and the ecological changes is much more difficult to understand and quantify

\footnotetext{
* Corresponding author at: University of Liège, Mathematical Methods and Modelling, SartTilman B37, B-4000 Liège, Belgium. Tel.: +32 4 3669419; fax:+32 4 3669489.

E-mail address: E.Delhez@ulg.ac.be (É.J.M. Delhez).
}

(Debelius et al., 2011-this issue). The highly dynamic nature of coastal ecosystems adds to the complexity of the observation and modelling exercises (Wild-Allen et al., 2011-this issue). The natural variability of the system, and in particular the poorly known long term and inter-annual signals (Best et al., 2011-this issue), superimposes also on the impact of human pressures. The assessment of the functioning of coastal systems and their response require therefore that the inter-related biological, physical, chemical and socioeconomic aspects be taken into account, fostering the collaboration of a large number of specialists in interdisciplinary networks.

In order to address the different threats to coastal systems, all major national and international environmental agencies have set up programmes to support the Integrated Coastal Zone Management (ICZM). There is indeed an urgent need to increase the scientific knowledge needed to support the implementation of local legislations and policies (like the EU Water Framework Directive and the Marine Strategy Directive), to assess the impact of different scenarios of coastal activities, to support management decisions and to promote sustainable use of coastal resources. The development of appropriate tools and methods is however a particularly complex task. As pointed out by Maes et al. in their talk (Maes J., De Kok J.L., Engelen G., and Hopkins T.S., Scientific integrated coastal system assessment: a paradox.41st International Liège Colloquium on Ocean Dynamics, Liège, May 2009), "the differences in scientific paradigms of the different partners, the limitations of the scientific and modelling expertise and the lack of a true interdisciplinary education of the scientific community form the main obstacles for integrated research".

\section{Acknowledgments}

In the name of the Scientific Committee and of the local Organizing Committee, we thank the National Science Foundation of Belgium (F. R.S.-FNRS), the Ministry of Education and Research and the University of Liège for their valuable support.

\section{References}

Best S., Lundrigan S., Demirov E. and Wroblewski J., this issue. Interannual variability of physical oceanographic characteristics of a marine protected area in Labrador, Canada. Journal of Marine Systems.

Casella E., Ferraris L., Molcard A., Provenzale A. and Zakardjian B., this issue. Mesoscale vortices in the Ligurian Sea and their effect on coastal upwelling processes. Journal of Marine Systems.

Debelius B., Forja J.M., Lubián L.M., this issue. Toxicity of copper, nickel and zinc on synechococcus populations from the strait of Gibraltar. Journal of Marine Systems. Grayek S., Joanna Staneva, Johannes Schulz-Stellenfleth, Willhelm Petersen, and Emil V. Stanev, this issue. Ferrybox data in the German Bight: their contribution to the 
improvement of state estimates and numerical model predictions. Journal of Marine Systems.

Grifoll M., Jordà G., Espino M., Romo J. and García-Sotillo M., this issue. A management system for the water quality degradation in a harbor. Journal of Marine Systems.

Hoitink A.J.F., van Maren D.S. and Hoekstra P., this issue. Mixing and stratification in a tropical tidal embayment subject to a distributed freshwater source. Journal of Marine Systems.

Hu Z.Y., Petrenko A. A., Doglioli A. M. and Dekeyser I., this issue. Study of coastal eddies: applications in the Gulf of Lion. Journal of Marine Systems.

Iosjpe M., this issue. A sensitivity analysis of the parameters controlling watersediment interactions in the coastal zone: consequences to man and environment. Journal of Marine Systems.
Pairaud L., Gatti J., Bensoussan N., Verney R. and Garreau P., this issue. Circulation in a coastal area off Marseille from 3D modelling and observations. Journal of Marine Systems.

Ribas F., de Swart H.E., Calvete D. and Falqués A., this issue. Modelling waves, currents and sandbars in natural beaches: the effect of surface rollers. Journal of Marine Systems.

Soomere T., Parnell K.E., Didenkulova I., this issue. Water transport in wake waves from high-speed vessels. Journal of Marine Systems.

van den Berg N., Falqués A. and Ribas F., this issue. Long term evolution of nourished beaches under high angle wave conditions. Journal of Marine Systems.

Wild-Allen K., Thompson P., Volkman J. and Parslow J., this issue. Use of a coastal biogeochemical model to select environmental monitoring sites. Journal of Marine Systems. 